\title{
Immunological Studies on Soluble Protective Antigen (SPA) Separated from Culture Supernatant Fluids of Salmonella enteritidis
}

\author{
Keiichi UCHIYA and Hisayoshi SUGIHARA \\ Department of Microbiology, Faculty of Pharmacy, Meijo University Tenpaku-ku Nagoya 468, Japan
}

Key words: Purified SPA of Salmonella enteritidis, Lipopolysaccharide,

Ouchterlony immunodiffusion, Delayed footpad test,

Macrophage migration inhibitory test

\begin{abstract}
Studies were carried out to analyze the antigenicity of Soluble Protective Antigen (SPA) separated from culture supernatant fluids of Salmonella enteritidis strain 2547. Mice injected with anti-SPA mouse serum were capable of tolerating a challenge dose of $100 \mathrm{LD}_{50}$ S. enteritidis. After absorption of the anti-SPA mouse serum with lipopolysaccharide (LPS) prepared from strain 2547, no protective effect was observed. Ouchterlony immunodiffusion analysis showed that the P1 fraction obtained from Sephadex G-50 gel filtration of strain 2547 or 2822 LPS reacted with antiserum to SPA, but no reaction was observed with the $\mathrm{P} 2$ or P3 fraction. The LPS from strain 2547 gave $80 \%$ mouse protection against challenge with $100 \mathrm{LD}_{50}$ of the homologous bacteria, while the P1 from strain 2547 LPS afforded 40\% protective immunity. When P1, LPS and SPA were transferred into the footpad of SPA-immunized mice, a positive delayed footpad reaction was elicited. Similarly, macrophage migration inhibitory activity was observed when SPA-induced peritoneal exudate cells were cultured in medium containing P1, LPS and SPA. These results suggest that the antigenic determinatant of SPA exists in the O-antigenic components of LPS.
\end{abstract}

\section{Introduction}

Mouse infections with Salmonella enteritidis have been studied as a model of human typhoid infection. It has been generally accepted that antigen-specific $\mathrm{T}$ lymphocytes play the major role in the development of immunity to intracelluar bacterial parasites ${ }^{1}$. Several investigators have shown that effective resistance to $S$. enteritidis, one of the facultative intracellular bacteria, is based on cell-mediated immunity induced only by live vaccine ${ }^{233}$. However, there are many reports showing that non-viable vaccine is effective against Salmonella infection ${ }^{45)}$. Plant et al. ${ }^{6}{ }^{6}$ reported that a supernatant factor prepared from cultures of $S$. typhimurium protects mice against a subcutaneous challenge dose of $100 \mathrm{LD}_{50} \mathrm{~S}$. typhimurium. In this laboratory it has been shown that mice immunized by a single injection of Soluble Protective Antigen (SPA) separated from the culture fluids of $S$. enteritidis strain 2547 tolerated a challenge against $10,000 \mathrm{LD}_{50}$ of the same organism strain ${ }^{7}$, and that both cellular and humoral immune responses are significant in this protective mechanism ${ }^{819)}$. In previous studies, chemical analysis of SPA confirmed the presence of lauric, myristic, palmitic and 3-hydroxymyristic acid which are common constituents of the lipid A moiety. Furthermore, SPA enhanced both the plaque-forming cell (PFC)-response to sheep erythrocytes and the clotting activity of Limulus amebocyte lysate (unpublished data). These results indicated that SPA possesses the properties of LPS extracted from bacteria by chemical methods. In order to examine this

別刷請求先：（干468）名古屋市天白区天白町八事裏山15

名城大学薬学部微生物学教室 杉原 久義 
aspect in more detail, antigenic analyses of SPA were conducted.

\section{Materials and Methods}

Animals.

Female mice of ddy strain were purchased from the Shizuoka Laboratory Animal Center, Hamamatsu, Japan. Mice were used at the age of 7-8 weeks.

Organisms.

Salmonella enteritidis strain 2547 and 2822 were maintained in our laboratory. The bacteria were passaged once in ddy mice before use in this study. Fresh isolates were obtained from the spleen on day 2 postinoculation. S. enteritidis was cultured in liver and beef papain digestion agar medium at $37^{\circ} \mathrm{C}$ for 18 hr. The $\mathrm{LD}_{50}$ value by the intraperitoneal route of $S$. enteritidis strain 2547 for ddy mice was $1 \times 10^{7}$ colony-forming units.

Preparation of purified SPA and lipopolysaccharide (LPS).

The purified SPA was prepared as described previously ${ }^{10)}$. LPS was extracted from S. enteritidis with hot phenol-water according to the method of Westphal et $a l^{11)}$. The extracted LPS was repeatedly centrifuged at $100,000 \times \mathrm{g}$ for $2 \mathrm{hr}$ to remove contaminating RNA and lyophilized.

Transfer experiments of absorbed anti-SPA mouse serum.

Ten mice were immunized intraperitoneally (i.p.) with $0.5 \mathrm{ml}$ of a saline solution containing SPA (20 $\mu \mathrm{g} / \mathrm{ml})$. The mice were sacrificed 14 days after immunization and the serum was separated and inactivated by heating at $56^{\circ} \mathrm{C}$ for $30 \mathrm{~min}$. The inactivated serum obtained was used as anti-SPA mouse serum. The antiserum was absorbed with $5 \%$ by volume of SPA or LPS. The mixture was kept at $37^{\circ} \mathrm{C}$ for $1 \mathrm{hr}$ and then transferred i.p. to normal mice $(0.5 \mathrm{ml} /$ mouse). Experimental groups consisted of 5 mice which were challenged i.p. 30 min later with $100 \mathrm{LD}_{50}$ of strain 2547.

Degradation of lipopolysaccharide and fractionation of the carbohydrate moiety.

Eighty milligrams of LPS from S. enteritidis strain 2547 or 2822 in $10 \mathrm{ml}$ of $1 \%$ acetic acid was heated at $100^{\circ} \mathrm{C}$ for $1.5 \mathrm{hr}$. The reaction mixture was centrifuged at $2,000 \times \mathrm{g}$ for $15 \mathrm{~min}$ in order to remove lipid A. The supernatant was lyophilized and used as the carbohydrate moiety (degraded polysaccharide). Gelchromatography of the degraded polysaccharide was carried out with a Sephadex G-50 column $(2.6 \times 100$ $\mathrm{cm}$ ) equilibrated with pyridine/acetic acid/water (10:4:1000 v/v/v). Fractions of $1.5 \mathrm{ml}$ were collected and tested with phenol sulphuric acid according to the method of Dubois et al. ${ }^{12)}$.

Preparation of antiserum.

Antiserum against SPA was prepared by immunizing rabbits according to the following procedure. One hundred micrograms of purified SPA was thoroughly emulsified with $2.0 \mathrm{ml}$ of Freund's complete adjuvant. The emulsion was injected intradermally to Japanese white rabbits weighing about $2.0 \mathrm{~kg}$, once a week for 5 successive weeks. Rabbits were bled 1 week following the last injection and the serum was separated by centrifugation.

Delayed footpad test.

Mice were immunized i.p. with $10 \mu \mathrm{g}$ of SPA, and tested 14 days following immunization for the presence of delayed-type hypersensitivity (DTH) by measuring footpad swelling. Three fractions (P1, P2 and P3) obtained by gel chromatography of strain 2547 LPS, SPA and LPS were used as antigens for eliciting the footpad response. The eliciting antigens $(1 \mu \mathrm{g})$ suspended in $0.1 \mathrm{ml}$ of saline were injected into the right hind footpad, and saline alone was injected into the left hind footpad as a control. The thickness of the footpad was measured with dial-gauge calipers (KSM-150, KANON, Japan) just before injection of antigen and at $24 \mathrm{hr}$ following injection. The thickness of the saline-injected footpad was subtracted from that of the antigen-injected footpad to yield the difference in footpad thickness for each mouse. DTH in 
nonimmunized mice was analyzed in a similar manner.

Macrophage migration inhibition test (MIT) ${ }^{13)}$.

Ten mice were immunized i.p. with $10 \mu \mathrm{g}$ of SPA. To induce macrophage-rich peritoneal exudate cells, mice were injected i.p. with $2 \mathrm{ml}$ of $10 \%$ (w/v) proteose peptone at 11 days following immunization. Three days after the injection, peritoneal exudate cells were collected by peritoneal irrigation with Eagle minimum essential medium (Nissui pharmaceutical Co., Ltd, Tokyo, Japan) containing L-glutamine, 100 units $/ \mathrm{ml}$ of penicillin $\mathrm{G}$ and $100 \mu \mathrm{g} / \mathrm{ml}$ of streptomycin (MEM-PS). The cell suspensions were washed and suspended by adding $0.4 \mathrm{ml}$ volumes of MEM-PS containing $15 \%$ heat-inactivated normal guinea-pig serum. The cells were then packed into capillary tubes, and incubated at $37^{\circ} \mathrm{C}$ for $24 \mathrm{hr}$ in tissue culture medium or in medium containing the P1, P2 or P3 fraction ( $50 \mu \mathrm{g} / \mathrm{ml}$ ) from strain $2547 \mathrm{LPS}$, SPA or LPS ( $4 \mu \mathrm{g} / \mathrm{ml})$. The areas of migration were measured and expressed as percent migration inhibition by the formula presented in Table 3.

\section{Results}

Protective effect by passive transfer of absorbed anti-SPA mouse serum. The protective effect of anti-SPA mouse serum absorbed with LPS obtained from the same strain 2547 was investigated (Table 1). When normal mice were challenged with $100 \mathrm{LD}_{50}$ of strain 2547 after passive transfer of anti-SPA mouse serum, $100 \%$ of the mice survived. After absorption of the anti-SPA mouse serum with SPA or LPS, the injection was no longer effective against infection.

Fractionation of the degraded polysaccharide by gel chromatography. In order to separate the polysaccharide portion and lipid A, LPS was hydrolyzed in $1 \%$ acetic acid at $100^{\circ} \mathrm{C}$ for $1.5 \mathrm{hr}$. Lipid A was removed from the reaction mixture by centrifugation and the supernatant was used as the degraded polysaccharide. The elution profile of the degraded polysaccharide isolated from strain 2547 or 2822 LPS in gel filtration on a Sephadex G-50 column showed three distinct peaks which correspond to P1, P2 and P3 (Fig. 1). By quantitative sugar analysis of the three fractions, it was demonstrated that P1, P2 and P3 consist of the polymeric O-specific side chain with attached core, core oligosaccharide and the monosaccharide fraction (chiefly 2-keto-3-deoxyoctonate), respectively (data not shown). The elution pattern of P1 and P3 from strain 2547 was very similar to that of strain 2822, whereas P2 from strain 2822 emerged slightly earlier than that of strain 2547.

Immunological properties. Immune precipitation patterns for P1, P2 and P3 of strain 2547 and 2822 LPS versus the antibody preparation to pure SPA are shown in Fig. 2. P1 obtained from strain 2547 or 2822 LPS reacted strongly with antiserum to SPA, however, no reaction was observed with P2 or P3.

Protective effect of each fraction obtained from gel chromatography. Each fraction obtained from Sephadex G-50 gel filtration of strain 2547 LPS was tested for its ability to protect mice against the

Table 1 Protective effect of passively transferred absorbed-sera

\begin{tabular}{cc}
\hline Treatment $^{\mathrm{a})}$ & Survival(\%) \\
\hline None & 100 \\
LPS & 0 \\
SPA & 0 \\
\hline
\end{tabular}

a) Anti-SPA mouse serum was absorbed with SPA or LPS at $37^{\circ} \mathrm{C}$ for $1 \mathrm{hr}$. Absorbed serum was passively transferred to normal mice (i.p.), and after $30 \mathrm{~min}$ utes, the mice were challenged i.p. with $100 \mathrm{LD}_{50}$ or $S$. enteritidis strain 2547. 
Fig. 1 Fractionation on Sephadex G-50 of degraded polysaccharide obtained from the LPS of S. enteritidis strain 2547 and 2822 . Eighty $\mathrm{mg}$ of LPS was heated in $10 \mathrm{ml}$ of $1 \%$ acetic acid at $100^{\circ} \mathrm{C}$ for 1.5 hours, and centrifuged at 3500 r.p.m. for $15 \mathrm{~min}$. The supernatant was applied to a gelfiltration column of Sephadex G-50 $(2.6 \times 100 \mathrm{~cm})$ equilibrated with pyridine-acetic acid-water $(10: 4: 1000 \mathrm{v} / \mathrm{v} / \mathrm{v})$. The column was developed at a flow rate of $3.7 \mathrm{ml} / \mathrm{h}$, and $1.5 \mathrm{ml}$ fractions were collected. Aliquots were tested with phenol sulphuric acid and absorbance was measured at 485 nm.

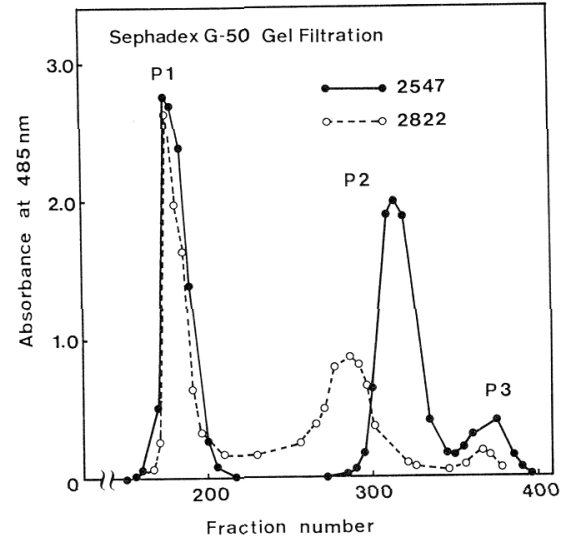

Fig. 2 Ouchterlony immunodiffusion analysis. Well A, C and E: P1, P2 and P3 obtained from $S$. enteritidis 2547 LPS, respectively; Well B, D and F: P1, P2 and P3 obtained from S. enteritidis 2822 LPS, respectively; Center well: Anti-pure SPA Rabbit serum. P1, P2 and P3 fractions are shown in Fig. 1.

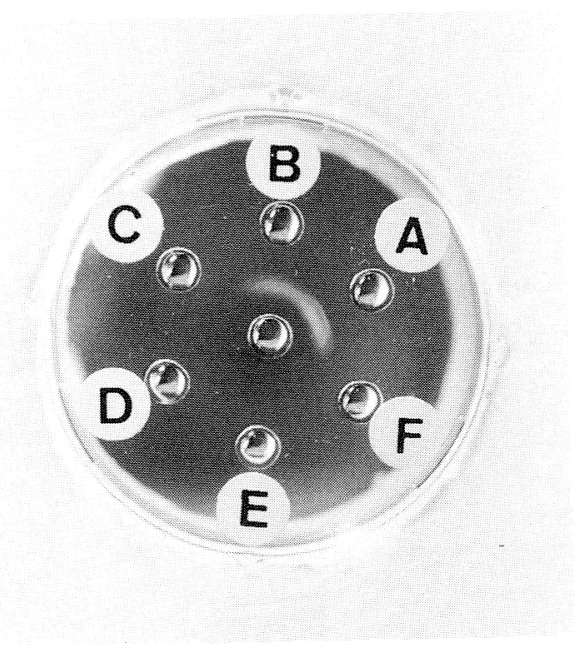

Fig. 3 Protective ability of mice immunized with each fraction obtained from Sephadex G-50 gel filtration of S. enteritidis strain 2547 LPS. Mice were immunized i.p. with $0.5 \mathrm{ml}$ of each fraction, and challenged i.p. 14 days later with $100 \mathrm{LD}_{50}$ of S. enteritidis. P1 fraction $(\bigcirc-\bigcirc), \mathrm{P} 2(\triangle-\triangle), \mathrm{P} 3$ $(\square-\square)$, and P Mix -0$),$ P1, P2 and P3 fractions are shown in Fig. 1.

A- $\mathbf{A}$ : 2547 LPS, $\mathbf{a}$ : Control.

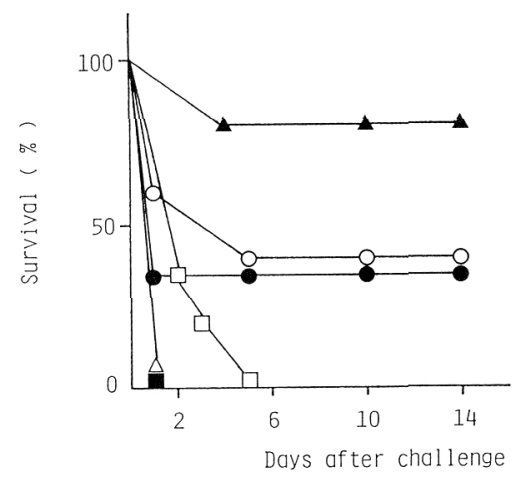

Table 2 Delayed footpad reaction in mice after immunization with SPA

\begin{tabular}{|c|c|c|}
\hline \multirow{2}{*}{ Antigen } & Immunized mice $\mathrm{e}^{\mathrm{a})}$ & $\begin{array}{c}\text { Nonimmunized } \\
\text { control mice }\end{array}$ \\
\hline & $\operatorname{DFR}(\times 0.1 \mathrm{~mm})^{\mathrm{b})}$ & $\operatorname{DFR}(\times 0.1 \mathrm{~mm})$ \\
\hline Saline & $-0.28 \pm 0.62$ & $-0.13 \pm 0.48$ \\
\hline $\mathrm{P} 1$ & $3.34 \pm 0.35$ & $0.33 \pm 0.53$ \\
\hline $\mathrm{P} 2$ & $0.94 \pm 0.43$ & $0.28 \pm 0.64$ \\
\hline P3 & $1.61 \pm 0.15$ & $1.72 \pm 0.15$ \\
\hline LPS & $3.94 \pm 0.40$ & $-0.22 \pm 0.49$ \\
\hline SPA & $5.17 \pm 0.58$ & $-0.78 \pm 0.05$ \\
\hline
\end{tabular}

a) Mice were immunized i.p. with SPA, and after 14 days injected in the footpad with each antigen.

b) DFR, Delayed footpad reaction measured $24 \mathrm{hr}$ after elicitation with each antigen.

P1, P2, and P3 were obtained from Sephadex G-50 gel filtration of $S$. enteritidis strain 2547 LPS. Mean \pm SEM 
Table 3 Macrophage migration inhibition test in mice immunized with SPA

\begin{tabular}{cc}
\hline Antigen & Migration inhibition(\%) ${ }^{\text {a) }}$ \\
\hline P1 & $30.38 \pm 4.43$ \\
P2 & $1.48 \pm 3.48$ \\
P3 & $5.84 \pm 3.71$ \\
LPS & $31.20 \pm 0.93$ \\
SPA & $29.89 \pm 2.24$ \\
a) Migration inhibition was determined using the following \\
formula : \% inhibition=100 - (mean area of migration in \\
the presence of antigen/mean area of migration in the \\
absence of antigen) $\times 100$. P1, P2, and P3 were obtained \\
from Sephadex G-50 gel filtration of S. enteritidis strain \\
2547 LPS.
\end{tabular}

Mean \pm SEM

challenge using the same strain. Groups of five mice were immunized i.p. with $0.5 \mathrm{ml}$ of the P1, P2 or P3 fractions, and challenged i.p. 14 days later with $100 \mathrm{LD}_{50}$ of strain 2547. As shown in Fig. 3, the LPS prepared from strain 2547 provided $80 \%$ protection to mice as determined by survival rate at 14 days after challenge, whereas only $40 \%$ protection was achieved with the P1 or the mixture of P1, P2 and P3. All mice immunized with P2 or P3 died following the challenge.

Delayed footpad reaction of SPA-immunized mice. Mice were immunized with SPA, and the delayed footpad reaction was measured using various eliciting antigens. When P1 from strain 2547 LPS, SPA or LPS were used as eliciting antigens, the DTH response was observed (Table 2). Neither P2 nor P3 eliciting antigens developed the DTH response.

MIT in SPA-immunized mice. The MIT was carried out with peritoneal exudate cells obtained from mice immunized with SPA. As shown in Table 3, positive inhibition of macrophage migration was observed when the cells were cultured in medium containing P1 from strain 2547 LPS, SPA or LPS. Neither the P2 nor the $\mathrm{P} 3$ antigen gave positive results in this test.

\section{Discussion}

It has been considered that resistance to Salmonella infection is mediated by cellular immunity but not by humoral immunity. However, previous works in this laboratory have shown that immunization with SPA induces high levels of protection against Salmonella challenge, and that the protective capacity of SPA is attributed to the ability of eliciting both cellular and humoral immune responses in the host ${ }^{819)}$. In this report, passive transfer of anti-SPA mouse serum was shown to protect mice against infection with $S$. enteritidis, whereas the protective activity was completely lost by absorption of the anti-SPA mouse serum with LPS extracted from strain 2547. These observations strongly suggest that the protective effect in passive protection experiments is a consequence of anti-LPS antibodies.

In general, LPS can be split under mild acidic conditions ( $1 \%$ acetic acid, $100^{\circ} \mathrm{C}, 1.5 \mathrm{hr}$ ) into two principal fractions, lipid A and the polysaccharide portion, the latter usually being referred to as degraded polysaccaride. The degraded polysaccharide of the usual gram-negative bacterial LPS can be fractionated on Sephadex G-50 into three distinct peaks. It has also been shown that the first peak eluted in the void volume corresponds to the polymeric $\mathrm{O}$-specific side chain, the second peak to core oligosaccharide and the third peak to the monosaccharide fraction that contains predominantly $\mathrm{KDO}^{14}$. In these experimetns, the elution pattern of degraded polysaccharide isolated from strain 2547 or 2822 LPS was consistent with the 
reports described above. The P1 fraction obtained from Sephadex G-50 gel filtration of strain 2547 or 2822 LPS formed a precipitin band in an Ouchterlony immunodiffusion assay against anti-SPA rabbit serum, but P2 and P3 did not. Additionally, it has been found that SPA can induce a delayed footpad reaction and macrophage migration inhibitory activity ${ }^{9}$, which are regarded as parameters of cellular immunity. When P1 was transferred into the footpad of SPA-immunized mice, a positive delayed footpad reaction was elicited. Similarly, macrophage migration inhibitory activity was observed when SPA-induced peritoneal exudate cells were cultured in medium containing P1. These results suggest that the antigenic determinant of SPA is related to $\mathrm{O}$-antigenic components of LPS.

Crutchley, et al. ${ }^{15)}$ showed that a lipopolysaccharide endotoxin was released into the culture fluid of a wide variety of Gram negative organisms. Jorgensen, et al. ${ }^{16)}$ demonstrated that liberation of lipopolysaccharide was due to solubilization or shedding of preexisting cell wall material, and not a consequence of metabolic overproduction of this material; nor was it a result of cellular lysis. Previous studies have shown that SPA contains a lipid A moiety, and possesses the properties of LPS extracted from bacteria by chemical procedures. The conclusion from these results is that SPA is part of the LPS that is released into the liquid environment as a result of the solubilization of bacterial cell wall material; and is composed of lipid A and core material. However, SPA alone can induce significant protection against the challenge of $10,000 \mathrm{LD}_{50}$ of $S$. enteritidis strain 2547 . LPS and P1 from strain 2547 only afforded $80 \%$ and $40 \%$ protective immunity against the challenge of $100 \mathrm{LD}_{50}$ of homologous bacteria. Although SPA is certainly part of the LPS that is released into the liquid environemnt, it seems that the physiochemical capabilities of the SPA differs markedly from the LPS isolated by chemical procedures.

\section{Acknowledgements}

Thanks are due to Dr. T. Nikai for very helpful discussions, and to Miss S. Kawai for technical assistance.

\section{References}

1) Collins, F.M.: Cellular antimicrobial immunity. Crit. Rev. Microbiol., 7: 27-91, 1979.

2) Ushiba, D., Saito, K., Akiyama, T., Nakano, M., Sugiyama, T. \& Shirono, S.: Studies on experimental typhoid: Bacterial multiplication and host cell response after infection with Salmonella enteritidis in mice immunized with live and killed vaccines. Japan J. Microbiol., 3: 231-242, 1959.

3) Mackanes, G.B. \& Blanden, R.V.: Cellular immunity. Prog. Allergy, 11: 89-140, 1967.

4) Venneman, M.R.: Purification of immunogenically active ribonucleic acid preparations of Salmonela typhimurium: molecular-sieve and anion-exchange chromatography. Infect. Immun., 5: 269-282, 1972.

5) Svenson, S.B., Nurminen, M. \& Lindberg, A.A.: Artificial Salmonella vaccines: O-antigenic oligosaccharide-protein conjugates induce protection against infection with Salmonella typhimurium. Infect. Immun., 25: 863-872, 1979.

6) Plant, J., Glynn, A.A. \& Wilson, B.M.: Protective effects of a supernatant factor from Salmonella typhimurium on Salmonella typhimurium infection of inbred mice. Infect. Immun., 22: 125-131, 1978.

7) Kamiya, K., Sugihara, H. \& Tanaka, T.: Basic studies on prevention of experimental salmonellosis (4). Purification of S. enteritidis SPA. J.J.A. Inf. D., 56: 126-133, 1982.

8) Kamiya, K., Sugihara, H. \& Tanaka, T.: Basic studies on prevention of experimental salmonellosis (5). Humoral immune responses in protective immunity with purified SPA of S. enteritidis. JJ.A. Inf. D., 56: 671-678, 1982.

9) Kamiya, K. \& Sugihara, H.: Basic studies on prevention of experimental salmonellosis (6). Cellular immunity in the protective mechanism with purified SPA of Salmonella enteritidis. J.J.A. Inf. D., 57: 33-39, 1983.

10) Uchiya, K. \& Sugihara, H.: Enhancing effect of Salmonella enteritidis SPA on nonspecific resistance. J.J.A. Inf. D., 63: 463-470, 1989.

11) Westphal, O. \& Jann, K.: Bacterial lipopolysaccharides. Extraction with phenol-water and further applications of the procedure. Methods Carbohydr. Chem., 5: 83-91, 1965.

12) Dubois, M., Gilles, K.A. Hamilton, J.K., Rebers, P.A. \& Smith, F.: Colorimetric method for determination of sugars and related substance. Anal. Chem., 28: 350-356, 1956. 
13) Morley, J., Wolstencroft, R.A. \& Dumonde, D.C.: Measurement of lymphokines. In Handbook of Experimental Immunology. (Weir, D.M. ed.) p.27.1-27.28, Mansell, Oxford, 1978.

14) Jann, B., Reskie, K. \& Jann, K.: Heterogeneity of lipopolysaccarides. Analysis of polysaccharide chain lengths by sodium dodecylsulfatepolyacrylamide gel electrophoresis. Eur. J. Biochem., 60: 239—246, 1975.

15) Crutchley, M.J., March, D.G. \& Cameron, J.: Biological studies of free endotoxin and non-toxic material from culture superatant fluids of Escherichia coli 078 K80. J. Gen. Microbiol., 50: 413-420, 1968.

16) Jorgensen, F.H. \& Smith, R.F.: Measurment of found and free endotoxin by the Limulus assay. Proc. Soc. Exp. Biol. Med., 146: 1024-1031, 1974.

\title{
Salmonella enteritidis 2547株 SPA の免疫学的研究
}

\author{
名城大学薬学部微生物学教室 \\ 打 矢恵一杉原 久 義 \\ （平成 1 年11月 28 日受付） \\ (平成 2 年 1 月 8 日受理)
}

Salmonella enteritidis 2547株の培養上清から 得られた可溶性感染防御抗原 (SPA) の抗原分析 を行った．抗 SPA マウス血清を投与されたマウ スは，100LD 50 の攻撃に耐える事ができる。しか し，2547株から分離した LPS でその血清を吸収 すると，もはやその防御効果は見られなかった。 オクタロニー法を用いた分析により，2547株又は 2822株 LPS の Sephadex G-50のゲル濾過により
得られた P1画分と抗 SPA 血清との間に沈降線 が見られた。 2547株 LPSは, $100 \mathrm{LD}_{50}$ の攻撃に対 して $80 \%$ の防御効果を示し, 一方 2547 株 LPS か らの PI 画分は, 40\%であった.SPA で免疫された マウスの後足蹠に, PI 画分, LPS, SPA を投与し た時, 遅延型足蹠反応が見られた。同様にマクロ ファージ遊走阻止活性が PI 画分, LPS, SPAを用 いた時に見られた。 